\title{
LIVESTOCK MORTALITY IN AFGHANISTAN IN DISTRICTS WITH AND WITHOUT A VETERINARY PROGRAMME
}

\author{
B. E. C. SCHREUDER ${ }^{1}$, N. NOORMAN ${ }^{2}$, M. HALIMI ${ }^{2}$ and G. WASSINK ${ }^{2}$
}

${ }^{\prime}$ DLO-Institute for Animal Science and Health, PO Box 65, Lelystad, The Netherlands; ${ }^{2}$ DCA-Veterinary Training and Support Centre, Monitoring Department, University PO Box 792, Peshawar, Pakistan

\section{SUMMARY}

This paper reports on livestock mortality in Afghanistan where a war has been going on for more than a decade, with complete disruption of the veterinary field services. The study attempted to measure the impact of a veterinary field programme carried out mainly by paravets. The study also provides valuable data on the impact of diseases in the absence of any veterinary intervention.

The veterinary programme, implemented by a Dutch non-governmental organisation (NGO) for approximately 3 years, consisted essentially of vaccination against major infectious diseases and administration of anthelmintic drugs for nematodes and liver flukes. Veterinary personnel were also involved in curative treatments.

Livestock mortality figures were collected by questionnaire over a period of 2 years from more than 700 farmers in randomly selected villages in 4 covered districts with a veterinary programme and 4 control districts without a veterinary programme.

The average annual mortality rates for calves, lambs and kids respectively were $16 \cdot 2 \%, 17 \cdot 3 \%$ and $19 \cdot 1 \%$ in the covered areas, against $21 \cdot 5 \%, 25 \cdot 2 \%$ and $24 \cdot 6 \%$ in the control areas. Adult mortality figures were $3 \cdot 8 \%, 7 \cdot 4 \%$ and $5 \cdot 4 \%$ in the covered areas, against $5 \cdot 3 \%, 13.6 \%$ and $15.6 \%$ in the control areas for cattle, sheep and goats respectively.

The survey indicated significant differences $(P<0.01$ in cattle, $P<0.001$ in small ruminants) in livestock mortality between the control and covered areas and it is concluded that these differences were attributable to the presence or absence of the animal health programme.

\section{Introduction, background and scope of the study}

The livestock sector is of major economic importance to Afghanistan providing many constituents of the diet and a source of income for more than $80 \%$ of the population. The Soviet invasion in December 1979 triggered off a decade of war in which complete villages, cities and most of Afghanistan's infrastructure, including irrigation canals, were destroyed. Human death toll exceeded one million and more than 5 million people, one-third of the population, fled the country. Rural Afghanistan witnessed a complete disruption of veterinary services, a situation still continuing over large areas. This has led to serious threats to the already decimated livestock population. The agriculture survey carried out by the Swedish Committee for Afghanistan (SCA) in 1988 indicated that numbers of livestock inside Afghanistan were approximately half of pre-war figures (SCA, 1988).

With the establishment in September 1988 of the Veterinary Training and Support Centre (VTSC) in Peshawar, Pakistan, by the Dutch Committee for Afghanistan (DCA), an emergency programme was commenced aimed at providing basic veterinary care for the remaining livestock population inside Afghanistan. In the company of several other non-governmental organisations (NGOs), DCA/VTSC tried to fill the gap in veterinary services created by the war and the reluctance or impossibility for 
specialised $\mathrm{UN}$-agencies to start operations in the absence of a central Government. The NGOs operated mainly in the eastern, central and southern parts of Afghanistan, having their bases in either Peshawar or Quetta in neighbouring Pakistan. In 1990, after the withdrawal of the Soviet army, the Food and Agriculture Organisation (FAO) of the United Nations also moved in with the aim of providing veterinary services to livestock holders in northern Afghanistan.

DCA/VTSC started in 1988 with the training of intermediate level veterinary auxiliary staff (paravets), for its own field programme but also for a number of other NGOs. In close consultation with local commanders or with other local authorities (shura) students were recruited from areas where need for veterinary assistance was identified. Upon graduation students were deployed in these areas inside Afghanistan within the structure of Veterinary Field Units (VFUs) under the supervision of higher qualified veterinary personnel. The personnel in the VFUs are expected to cover most of a district, each of them being assigned to a different duty station within that district. The actual extent of their coverage was not known at the time of the survey. Transport is a limiting factor, only the Officer in Charge of a VFU is provided with a motorcycle and other personnel move around on foot, bicycle or horseback.

The field programme was developed in close co-ordination with other NGOs involved in animal health and at a later stage with the United Nations Development Programme (UNDP). The DLO-Central Veterinary Institute (CDI-DLO) in the Netherlands provided technical support from inception of the project.

The tasks of the veterinary personnel are primarily to carry out preventive veterinary medicine plus some curative treatments. Vaccination campaigns are regularly carried out against anthrax, blackleg, enterotoxaemia, haemorrhagic septicaemia and Newcastle disease, the major infectious diseases in ruminants and poultry. Another important part of the programme is the provision and administration of anthelmintics for nematode and liver fluke infestations. In the absence of any recent reliable data, the field programme was based on disease reports from earlier FAO projects (FAO, $1955 ; 1973$ ) which stressed the importance of parasitic diseases. This is in line with the first author's own field experience in the north-eastern provinces of Afghanistan.

At the time of the survey all vaccines and veterinary drugs were supplied through the project; for the latter a gradually increasing cost-recovery was introduced.

The programme evolved gradually from an emergency orientated one to a programme for rehabilitating veterinary infrastructure and services. The first VFU was established in the spring of 1989 and by the end of 1992 the programme covered, to a varying degree, 33 districts in 13 out of 29 provinces. These were concentrated in the east-central, north-eastern and eastern regions (Fig. 1). In certain districts field activities had been going on for 3 years allowing an evaluation of the impact of the programme.

This paper reports a study to evaluate DCA's programme to provide veterinary services at village level based on training and support, mainly for paravets. The study compared livestock mortality in districts benefiting from the programme with adjacent or nearby districts that had been devoid of organised veterinary care for more than 10 years. The conditions entailed numerous practical and methodological difficulties and the survey of livestock-production and health under war-like conditions is unique. 
survey focused on collecting data on livestock productivity and mortality over a 2 year period by questionnaires to farmers. This report presents the data on livestock mortality only.

\section{Study population and selection of survey areas, villages and farmers}

Initially 7 districts with 2 to 3 years' functional animal health coverage provided by DCA/VTSC were selected in 6 different provinces in the central and eastern provinces of Afghanistan. These districts were designated the covered districts although the actual extent of the coverage was not precisely known. An equal number of control districts where no veterinary care had been made available for about 10 years were selected adjacent to the covered districts, and which were similar with respect to ecological conditions, animal husbandry practices and effects of war. This allowed a comparison between pairs of selected districts.

Using the Ministry of Interior Provisional Gazetteer, 3 villages were randomly selected within each selected district. In each selected village owners of 30 farms (10 large, average and small) were interviewed. With numbers of farmers varying between 15 and 70 between villages, it was assumed this sample was representative for the whole village. If an insufficient number of farmers was found in a selected village, the required number was added from an adjacent village. To qualify for analysis, a minimum number of 100 adult cattle and 200 adult sheep or goats was required for both years of the survey in the 3 villages selected in each district.

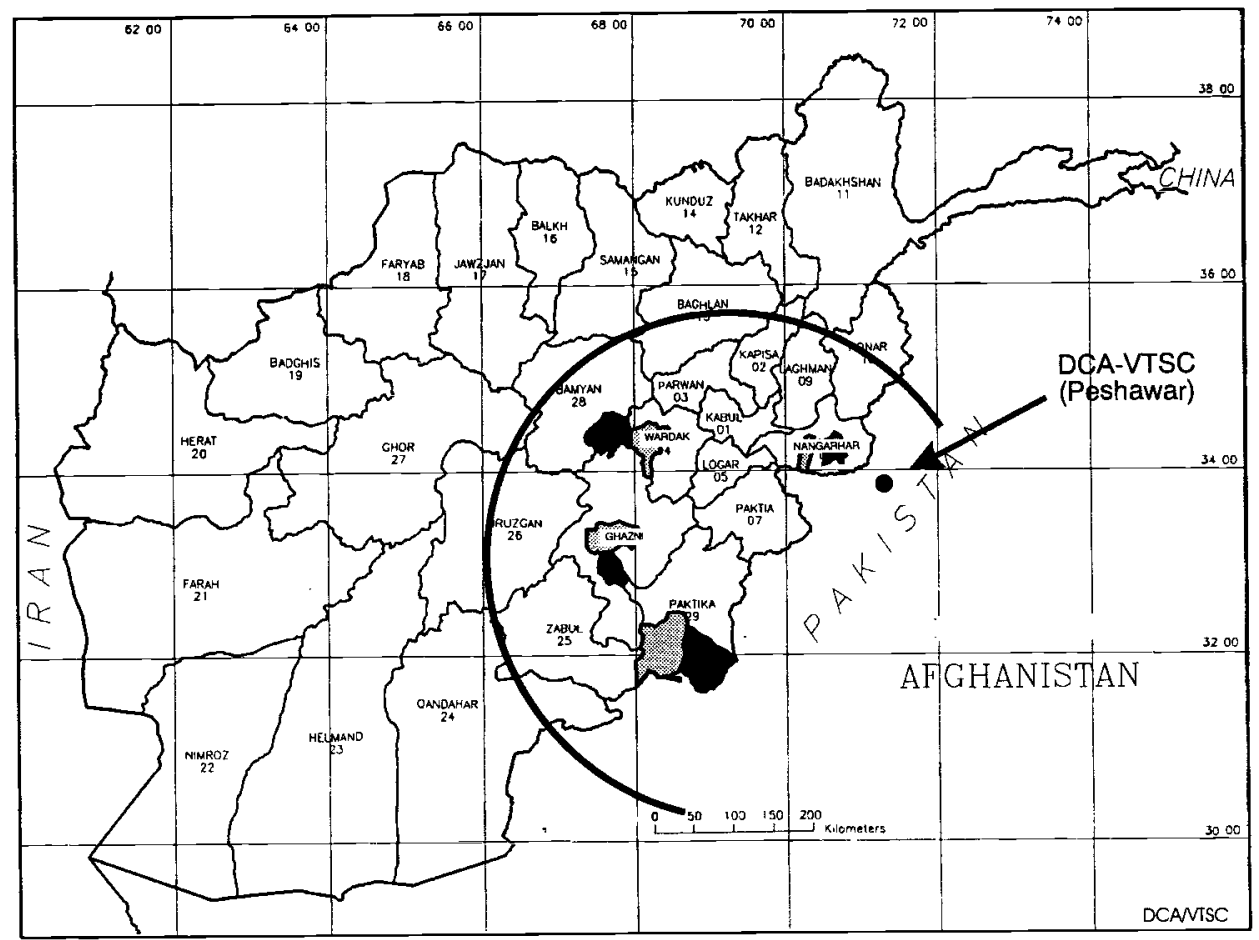

covered district

control district

C limit working area VTSC

Fig. 1. Districts in survey and working area of the VTSC. 


\section{The questionnaire}

The questionnaire was used in the summertime, well after the lambing season and the main calving season. The questions related to the 2 consecutive years immediately preceding the survey. An effort was made to distinguish between mortality among young and adult animals.

Questions were included on the presence or absence of animal health measures, the availability of medicines and anthelmintics, the numbers of livestock owned, summer migration, acreage for fodder crops, and animals killed by mines. In addition, the questionnaire contained several cross-check questions allowing internal checking. For example, not only the number of lambs born in a season was asked for, but also the numbers of ewes that lambed and number of twins born.

\section{The enumerators}

The enumerators administering the questionnaires were trained staff of the Agriculture Survey Department of the SCA, most of them having approximately 5 years experience in this field. The enumerators received additional instruction prior to their missions and were debriefed upon completion of the survey. The field work was carried out in the summer and early autumn of 1992 and it took each enumerator 2 months to complete his district.

\section{Analytical methods}

Results were analysed using Lotus spreadsheet program vs. 3. Data were analysed using Statcalc, the statistical module of EPI-INFO (epidemiology computer program, Center for Disease Control, Atlanta/WHO, Geneva). For calculating statistical differences between the individual pairs of districts and between the combined figures, a chi-square contingency table was used, uncorrected.

Annual adult mortality was defined as the number of adult animals that died (including emergency slaughter) during an observation period of one year as a proportion of the number of adult animals present at the start of the year. Adults were cattle that were over 18 months old or mated, and sheep and goats over 12 months old or mated, whichever came first.

For young small ruminants, mortality was defined as the number of young animals that died during the observation period as a proportion of the number of young animals born in the same observation period. However, because the survey was implemented in late summer to autumn, the observation period in the second year was only approximately 5 to 6 months, ie the period between the most recent lambing season and counting point.

For calves, mortality was defined as the number of calves that died during the observation period as a proportion of the number of calves born in or present at the start of the same observation period.

Animals sold, given away or consumed were asked for but not included in the calculations as these were apparently more than compensated for by the influx of young animals into the adult group. In the case of cattle, sales etc. involved less than $10 \%$ of the herd. In general, livestock were scarce in this period of rebuilding livestock numbers.

\section{RESULTS}

\section{Districts surveyed and districts qualifying for analysis}

The survey had been planned for 14 districts, however, the more northern provinces 
TABLE I

Pairs of districts included in the analysis

\begin{tabular}{lll}
\hline Province & Covered district & Control district \\
\hline Ghazni & Qarabagh & Moqur \\
Wardak & Day Mirdad & Behsud I \\
Nangarhar & Khogiani & Rodat \\
Paktika & Wazah Khwah & Wol Mamay \\
\hline
\end{tabular}

could not be reached due to severe fighting in the areas on the way. The survey was finally carried out in 10 districts in 4 provinces.

Two districts did not comply with the above described criteria with regard to presence or absence of an animal health programme and were therefore not included in the analysis. In the end, 4 pairs of districts in 4 different provinces remained for analysis (Table I; Fig. 1).

The average herd and flock sizes for cattle, sheep and goats were $5 \cdot 5,20$, and 13 respectively in the covered areas, and 6.0,32 and 26 in the control areas. The differences in flock sizes of small-ruminants were significant, however, because results did not indicate any significant difference in summer migration, acreage for fodder crops, feeding of concentrates, reproduction rate and number of animals killed by mines; paired comparison of the districts was considered acceptable.

\section{Livestock mortality in the control and covered districts}

Combined mortality figures for both years of the survey were analysed within each of the pairs of districts, and chi-square and P-values calculated for each pair (data not presented). The same was done for the overall figures combined for the 4 districts and for both years of the survey (Table II).

\section{Cattle}

In 2 of the 4 pairs a highly significant difference in favour of the covered districts was noted for adult cattle, and in 3 pairs for calves. The overall combined figures show a highly significant lower mortality $(P<0.01)$ in adults and in calves in the covered districts ( Table II ).

TABLE II

Annual livestock mortality in four pairs of districts in Afghanistan over a 2-year period

\begin{tabular}{|c|c|c|c|c|c|c|}
\hline & \multicolumn{2}{|c|}{$\begin{array}{c}\text { Districts covered } \\
\text { by veterinary services }\end{array}$} & \multicolumn{2}{|c|}{$\begin{array}{l}\text { Control districts } \\
\text { (not covered) }\end{array}$} & \multirow[b]{2}{*}{$x^{2}$} & \multirow[b]{2}{*}{$\mathrm{P}$} \\
\hline & $\begin{array}{l}\text { No. animals } \\
\text { at risk }\end{array}$ & $\begin{array}{c}\text { dead } \\
\text { No. }(\%)\end{array}$ & $\begin{array}{l}\text { No. animals } \\
\text { at risk }\end{array}$ & $\begin{array}{c}\text { dead } \\
\text { No. }(\%)\end{array}$ & & \\
\hline \multicolumn{7}{|l|}{ Adults } \\
\hline Cattle & 2217 & $84(3 \cdot 79)$ & 3227 & $171 \quad(5 \cdot 30)$ & $6 \cdot 7$ & $<0.01$ \\
\hline Sheep & 9047 & $745(8 \cdot 23)$ & 14433 & $1960(13 \cdot 58)$ & 157 & $<0.001$ \\
\hline Goats & 5814 & $349(6 \cdot 00)$ & 13701 & $2140(15 \cdot 62)$ & 339 & $<0.001$ \\
\hline \multicolumn{7}{|l|}{ Young } \\
\hline Calves & 974 & $158(16 \cdot 22)$ & 1217 & $262(21 \cdot 53)$ & $9 \cdot 8$ & $<0.01$ \\
\hline Lambs & 4830 & $837(17 \cdot 33)$ & 8621 & $2172(25 \cdot 19)$ & 110 & $<0.001$ \\
\hline Kids & 3343 & $639(19 \cdot 11)$ & 6524 & $1602(24 \cdot 56)$ & 37 & $<0.001$ \\
\hline
\end{tabular}




\section{Sheep}

In one district, numbers of sheep were considered too small $(<200)$ to allow proper comparison with its control. In each of the remaining districts a highly significant difference in favour of the covered district was noted for both adult sheep and lambs (data not presented). The overall combined figures show a very highly significant lower mortality $(\mathbf{P}<0.001)$ in both adults and lambs in the covered districts (Table II).

\section{Goats}

A highly significant difference in favour of the covered district was noted in adult goats in 4 of the pairs of districts and in kids in 3 pairs (data not presented). The overall combined figures show a very highly significant lower mortality $(\mathbf{P}<0.001)$ in both goats and kids in the covered districts (Table II).

In covered districts the mortality was roughly 25,30 , and $22 \%$ lower in calves, lambs and kids respectively, and roughly 30,40 and $60 \%$ lower in adult cattle, sheep and goats respectively.

\section{DISCUSSION}

This paper reports on livestock mortality figures in Afghanistan where a devastating war has been going on for more than a decade, with a complete disruption of the veterinary field services as one of the consequences. The study was an effort to measure in a number of districts, the impact of a veterinary field programme carried out mainly by paravets.

The impact of the programme was greatest for adult small ruminants which are by far the most numerous and important type of livestock in Afghanistan. The impact seemed lower, however, for adult cattle, also calves and young goats. An outbreak of rinderpest (serologically confirmed by CDI-DLO) in Nangarhar Province in 1991 may have confounded the picture for cattle mortality. This outbreak took place in the survey area, but due to lack of cold chain facilities, the project could not intervene adequately. The district pair in this province was the only pair in the survey where mortality in cattle was significantly higher in the covered district compared to the control district.

\section{Possible bias introduced by clustering of data}

The possibility of clustering data has not been addressed in this paper. Clustering will occur within farms and within villages. Elsewhere the possibility for clustering is much less, especially in the mountainous areas. The results of the statistical analysis of the combined data (Table II) should therefore be considered as indicative rather than as absolute values.

\section{Possible bias introduced by farmers or enumerators}

It is difficult to assess the amount of bias introduced by the farmers' answers to the questions. Farmers all over the world tend to adjust their statements out of self-interest; Afghan farmers will not be an exception. Conceivably farmers in areas without veterinary services may have exaggerated their problems hoping to receive these services earlier. It was a specific topic during the briefing of the enumerators to pay attention to this possibility.

The enumerators were trained and experienced in this field of work and had been recruited from a neutral organisation outside DCA-VTSC to avoid a possible bias 
introduced by using field staff involved in the veterinary programme. They had no direct interest in the outcome of the survey.

\section{The effect of the programme}

A highly significant difference in mortality of adult and young cattle, sheep and goats was demonstrated between the covered and control areas. The veterinary programme implemented in the covered areas for approximately 3 years, consisted mainly of a preventive vaccination programme against major infectious diseases such as anthrax, blackleg, enterotoxaemia and other clostridial diseases. In rare instances vaccination against foot-and-mouth disease was carried out. Another important part of the veterinary programme was the provision of anthelmintic drugs for nematodes and liver fluke. In addition, the field personnel were involved in curative treatments.

No effort was made to differentiate between the effects of the various components of the programme. Because infectious and parasitic diseases have always caused considerable losses to livestock in Afghanistan (FAO, 1955; 1973), it is assumed, however, that the preventive veterinary interventions have been responsible for most of the effect of the animal health programme.

In our opinion, the success of this programme was related to:

1. The integration of training, deployment and support provided by one organisation.

2. The recruitment of trainees from their future working areas.

3. A concise, practically orientated training for intermediate level of veterinary auxiliary personnel.

4. A guaranteed supply of vaccines, anthelmintics and other veterinary drugs (for which a cost-recovery was being gradually introduced).

5. As one of the sequels of the war, the absence of a rigid government-controlled veterinary structure allowing us to develop a new approach.

The data collected in the control districts may have a wider application and may serve as base-line data for assessing future interventions. The highly significant differences in mortality between the covered and control districts may contribute to the decision-making process on animal health and husbandry projects.

\section{ACKNOWLEDGEMENTS}

The assistance of Mart de Jong and Herman Barkema in the design of the study is gratefully acknowledged. Valuable support was received from Abdul Hakim Murad and Dr Azam Gul from the Agriculture Survey Department of the Swedish Committee for Afghanistan. This organisation also provided the enumerators, without whom the survey would have been virtually impossible. Finally, we want to acknowledge the veterinary field personnel of the Dutch Committee for Afghanistan and the Dutch Government Emergency Assistance Programme that supported the study financially.

Accepted for publication March 1995

\section{REFERENCES}

FAO (1955). The control of sheep diseases and parasites. (MACPhERson, D. A.) Report to the Government of Afghanistan. FAO Report No. 336, FAO, Rome.

FAO (1973). FAO technical report, (BLAGA, M. D.) UNDP/SF project 210 (AFG/511), Kabul.

SCA (1988). The agriculture survey of Afghanistan. Swedish Committee for Afghanistan. First Report, May. Peshawar, 68 pp. 


\section{MORTALITE DU BETAIL EN AFGHANISTAN DANS CERTAINS DISTRICTS AVEC OU SANS PROGRAMME VETERINAIRE}

Résumé-Cet article traite de la mortalité du bétail en Afghanistan où la guerre se poursuit depuis plus de 10 ans entraînant l'interruption complète des services vétérinaires locaux. L'étude essaye de mesurer l'impact d'un programme vétérinaire local mené principalement par des paravétérinaires. L'étude donne aussi des chiffres précieux sur l'impact de maladies lors de l'absence d'une intervention vétérinaire.

Le programme vétérinaire, mis en oeuvre par une organisation non-gouvernementale (ONG) hollandaise pour à peu près 3 ans, consista principalement en la vaccination contre les principales maladies infectieuses et l'administration de drogues anti-helminthiques contre les nématodes et certains trématodes. Le personnel vétérinaire fut aussi impliqué dans des traitements curatifs.

Les données sur la mortalité du bétail furent recueillies par questionnaire pendant à peu près 2 ans auprès de plus de 700 fermiers issus de villages choisis au hasard dans 4 districts couverts par un programme vétérinaire et dans 4 districts de référence sans programme vétérinaire.

La moyenne annuelle du taux de mortalité pour les veaux, les agneaux et les chevreaux fut respectivement $16,2 \%, 17,3 \%$ et $19,1 \%$ dans les districts couverts par le programme contre $21,5 \%, 25,2 \%$ et $24,6 \%$ dans les zones de référence. Les chiffres de mortalité pour les adultes sont de $3,8 \%, 7,4 \%$ et $5,4 \%$ dans les zones couvertes par le programme contre $5,3 \%, 13,6 \%$ et $15,6 \%$ dans les zones de référence respectivement pour les bovins, les mouteons et les chèvres.

L'étude présenta des différences significatives ( $\mathrm{P}<0,01$ pour les bovins, $\mathrm{P}<0,001$ pour les petits ruminants) dans la mortalité du bétail entre les zones de référence et celles couvertes par le programme. Il est apparu que ces différences sont dùes à l'absence du programme sanitaire pour les animaux.

\section{MORTALIDAD DEL GANADO EN AFGANISTAN EN DISTRITOS CON O SIN SEVICIOS VETERINARIOS}

Resumen-Est articulo aporta información acerca de la mortalidad del ganado en Afganistán, pais en el que una guerra que se inició hace más de diez años ha desorganizado los servicios veterinarios. El estudio cuantifica el efecto de un programa de asistencia veterinaria llevad a cabo principalmente por promotores pecuarios. Además, se aporta información acerca del impacto que las enfermedades tienen sobre el ganado cuando no existe asistencia veterinaria.

El programa de asistencia veterinaria, implementado por una organización no gubernamental (ONG) holandesa durante tres años aproximadamente, consistió en vacunaciones frente a las principales enfermedades infecciosas y en la administración de antihelmínticos para controlar infestaciones por nematodos y parásitos hepáticos. El personal veterinario también relaizó tratamientos curativos.

La información sobre la mortalidad del ganado se obtuvo mediante encuestas realizadas durante dos años a un total de 700 granjeros de poblados seleccionados al azar y situados en 4 distritos con asistencia veterinaria y en otros 4 distritos sin asistencia veterinaria.

La tasa anual de mortalidad media en terneros, corderos y cabritos fue del $16 \cdot 2,17 \cdot 3$ y $19 \cdot 1 \%$ respectivamente en las áreas con asistencia veterinaria, y de $21 \cdot 5,25 \cdot 2$ y $24 \cdot 6 \%$ en las áreas sin asistencia. Las tasas de mortalidad en vacunos, ovinos y caprinos adultos fue del $3 \cdot 8,7 \cdot 4$ y $5 \cdot 4 \%$ respectivamente en las áreas con asistencia y del $5 \cdot 3,13 \cdot 6$ y $15.6 \%$ en las áreas sin asistencia.

El estudió encontró diferencias significativas ( $P<0.01$ en vacuno, $P<0.001$ en pequeños rumiantes) en la mortalidad del ganado entre áreas con asistencia veterinaria y áreas sin asistencia. Se concluye que estas diferencia son atribuibles a la presencia o ausencia de un programa de sanidad animal. 